\title{
Peramalan Pola Curah Hujan Di Kota Makassar Menggunakan Model Rantai Markov
}

\author{
Hisyam Ihsan ${ }^{1}$, Wahidah Sanusi ${ }^{1}$, dan Hasriani ${ }^{1, \text { a) }}$ \\ ${ }^{1}$ Jurusan Matematika, Fakultas Matematika dan Ilmu Pengetahuan Alam, Universitas Negeri \\ Makassar, 90224 \\ a) hasriani_26@yahoo.com
}

\begin{abstract}
Abstrak. Rantai markov merupakan suatu metode yang mempelajari sifat-sifat suatu variabel pada masa sekarang yang didasarkan pada sifat-sifatnya dimasa lalu dalam usaha menaksir sifat-sifat variabel yang sama di masa yang akan datang. Salah satu metode yang umumnya digunakan dalam memprediksi kejadian yang akan datang adalah metode rantai markov diskrit. Tujuan penelitian ini adalah: (1) menentukan orde rantai markov yang digunakan dalam memprediksi curah hujan; (2) membentuk model rantai markov masing-masing stasiun dalam meramalkan curah hujan di Kota Makassar; (3) mengetahui hasil prediksi curah hujan masing-masing stasiun menggunakan rantai markov. Dengan menggunakan metode rantai markov diskrit maka dapat diperoleh hasil prediksi steady state Stasiun Panaikang pada periode ke-10 dengan peluang 0,35 bulan mengalami kondisi kering, 0,11 bulan mengalami kondisi lembab dan 0,55 bulan mengalami kondisi basah. Stasiun Biring Romang pada periode ke-15 dengan peluang 0,33 bulan mengalami kondisi kering, 0,08 bulan mengalami kondisi lembab dan 0,59 bulan mengalami kondisi basah. Sedangkan pada stasiun Paotere pada periode ke-12 dengan peluang 0,39 bulan mengalami kondisi kering, 0,06 bulan mengalami kodisi lembab dan 0,55 bulan mengalami kondisi basah.
\end{abstract}

Kata Kunci: Rantai Markov, Matriks Peluang Transisi, Orde Rantai Markov, Steady State.

\begin{abstract}
Markov chain is a method that studies the properties of a variable at the present time based on the nature of the properties in the past in an effort to estimate the properties of the same variable in the future. One of the methods commonly used in predicting the events that will be coming is the method of markov chain discrete. The purpose of this study is: (1) determine the order of the markov chain used in predicting the precipitation; (2) form the model of the markov chain each station in the predicted precipitation is in the City of Makassar; (3) know the results of the prediction of rainfall of each station using a markov chain. By using the method of markov chain discrete then it can be obtained the prediction results of the steady state Station Panaikang in the period of the 10th with a chance to 0.35 months experiencing dry conditions, of 0.11 months experience humid conditions and 0.55 months experience wet conditions. Station Biring Romang in the period of to-15 with a chance of 0.33 months experiencing dry conditions, of 0.08 months experience humid conditions and of 0.59 month is experiencing wet conditions. While on the station of Paotere in the period to 12 with opportunities to 0.39 months experiencing dry conditions, of 0.06 months experiencing the condition moist and 0.55 months experience wet conditions.
\end{abstract}

Keywords: Markov Chain, Matrix Transition Probability, Order of Markov Chain, Steady State 


\section{PENDAHULUAN}

Dalam kehidupan nyata, banyak fenomena alam yang memiliki ketidakpastian atau bersifat probabilistik, misalkan pergerakan lempengan bumi yang menyebabkan gempa, naik turunnya harga saham, keadaan cuaca, evolusi pasangan nukleotida, dan lain sebagianya. Salah satu model yang saat ini banyak dikembangkan adalah model rantai markov. Memodelkan fenomena alam dengan model Rantai Markov, diasumsikan bahwa proses yang terlibat didalamnya mengikuti sifat markov yaitu apabila diketahui proses berada dalam suatu keadaan tertentu, maka peluang berkembangnya proses di masa mendatang hanya tergantung pada keadaan saat ini dan tidak tergantung pada keadaan sebelumnya, atau dengan kata lain rantai markov adalah rangkaian proses kejadian dimana peluang bersyarat kejadian yang akan datang tergantung pada kejadian sekarang (Reza, 2007). Kelebihan dari metode rantai markov yaitu lebih mudah untuk digunakan dan simpel dibandingkan metode data mining lainnya sehingga dalam penerapannya untuk memprediksi keadaan cuaca atau curah hujan akan lebih mudah dilakukan (Nawangsari, 2008).

Curah hujan di Indonesia setiap tahunnya rata-rata tidak selalu sama. Variabilitas curah hujan yang besar bergantung dalam ruang dan waktu. Namun belakangan terjadi perubahan fisik atmosfir dari variabilitas komponen cuaca normal menuju kondisi ekstrim dalam kurun waktu yang panjang dan membawa dampak luas terhadap berbagai sektor kehidupan manusia (Paida, 2011).

Informasi yang berkaitan dengan kondisi di masa mendatang tidak dapat ditentukan secara pasti tetapi hanya dapat diprediksi atau diramalkan. Dalam peramalan curah hujan, dapat dilakukan dengan mngenali pola curah hujan di masa lalu, tentunya dengan parameter-parameter yang berpengaruh. Curah hujan memiliki pola yang hampir sama pada suatu periode tertentu dalam satu tahun. Walaupun ada perubahan, tetapi tidak begitu drastis. Peramalan curah hujan dapat dimanfaatkan untuk perencanaan pertanian dan peringatan dini banjir ataupun segala sesuatu yang berkaitan dengan pengaruh faktor hujan. Dalam peramalan curah hujan ada dua pendekatan yang dapat dilakukan yaitu faktor penyebab hujan dan data-data historis. Dalam penelitian ini akan dilakukan pendekatan data-data historis melalui data-data curah hujan dan tidak diperlukan data-data faktor penyebab curah hujan (Luk, 2001).

\section{KAJIAN PUSTAKA}

\section{Rantai Markov}

Rantai Markov adalahsuatu teknik matematika yang biasa digunakan untuk melakukan pemodelan bermacam-macam sistem dan proses bisnis. Teknik ini dapat digunakan untuk memperkirakan perubahan-perubahan di waktu yang akan datang dalam variabel-variabel dinamis atas dasar perubahan-perubahan dari variabel-variabel dinamis tersebut di waktu yang lalu. Teknik ini dapat digunakan juga untuk menganalisis kejadian-kejadian di waktu mendatang secara matematis (Dwijanto,2012). 


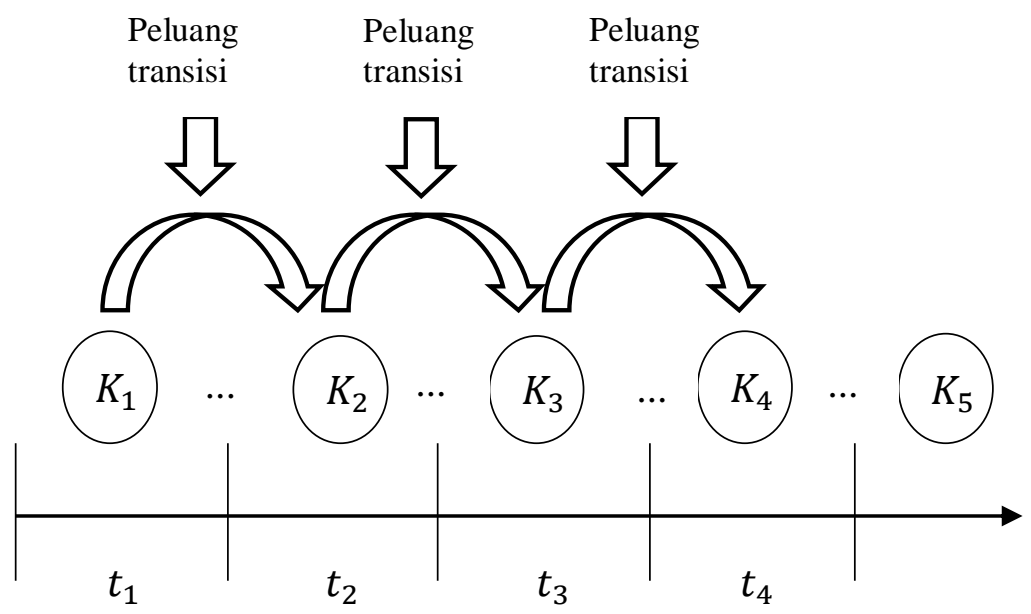

GAMBAR 1. Peristiwa Dalam Rantai Markov

Gambaran mengenai rantai markov dapat dilihat pada Gambar 1 dimana gerakan-gerakan dari beberapa variabel di masa yang akan datang bisa diprediksi berdasarkan gerakan-gerakan variabel tersebut pada masa lalu. Untuk setiap waktu t, ketika kejadian adalah Kt dan seluruh kejadian sebelumnya adalah $\mathrm{Kt}(\mathrm{j}), \ldots, \mathrm{Kt}(\mathrm{j}-\mathrm{n})$ yang terjadi dari Proses yang diketahui, peluang seluruh kejadian yang datang $\mathrm{Kt}(\mathrm{j})$ hanya bergantung pada kejadian $\mathrm{Kt}(\mathrm{j}-1)$ dan tidak bergantung pada kejadian-kejadian sebelumnya yaitu $\mathrm{Kt}(\mathrm{j}-2), \mathrm{Kt}(\mathrm{j}-3), \ldots, \mathrm{Kt}(\mathrm{j}-\mathrm{n})$.

Asumsi-asumsi dalam rantai markov adalah sebagai berikut:

a. Jumlah peluang transisi keadaan adalah 1 .

b. Peluang transisi tidak berubah selamanya.

c. Peluang transisi hanya tergantung pada status sekarang, bukan pada periode sebelumnya.

d. Kondisi merupakan kondisi yang independen sepanjang waktu.

\section{Orde Rantai Markov}

Andaikan peluang keadaan saat $n, X_{n}$ tidak hanya bergantung pada $X_{n-1}$ melainkan juga bergantung pada $X_{n-2}, X_{n-3}$, dan seterusnya, artinya kita bekerja dengan rantai markov yang disebut sebagai rantai markov berorde lebih dari satu (Reza, 2007).

\section{Uji Kesesuaian Suatu Rantai Markov}

Orde rantai markov ditentukan dengan cara memilih orde yang paling sesuai dari beberapa alternatif pilihan orde yang memungkinkan. Kemudian, yang perlu diperhatikan adalah sangat diharapkan bahwa orde bernilai serendah mungkin.

Menurut Reza (2007), langkah awal dalam melakukan uji ksesuaian, diasumsikan terlebih dahulu bahwa rantai markov tersebut $\sigma(r)$ dimana $r$ menyatakan orde maksimum yang dikehendaki oleh peneliti atau orde yang masih dapat ditoleransi oleh data. Selanjutya, bandingkan dengan yang terjadi jika rantai markov trsebut $\sigma(r-1)$. Dengan demikian, hipotesisnya adalah:

$$
\begin{gathered}
H_{0} \text { : penggunaan } \sigma(\mathrm{r}) \text { tidak berbeda dengan } \sigma(r-1) \\
H_{1} \text { : penggunaan } \sigma(\mathrm{r}) \text { berbeda dengan } \sigma(r-1)
\end{gathered}
$$

Menurut Anderson (2014), statistik uji distribusi chi kuadrat dengan derajat kebebasan $s^{r-1}(s-$ 1) $)^{2}$ yaitu,

$$
x^{2}=2 \sum_{i j k} n_{i j k}\left[\log p_{i j k}-\log p_{i j}\right]
$$




\section{Matriks Peluang Transisi}

Suatu proses markov terdefinisikan oleh matriks peluang transisinya.Sejumlah peluang transisi digunakan untuk menjelaskan persoalan dalam sistem yang membuat transisi dari suatu keadaan ke keadaan lainnya. Perilaku jangka panjang dari suatu proses markov ditandai oleh tidak adanya ketergantungan pada keadaan awal dari sistemnya. Hal ini bukan berarti sistem tersebut tetap dalam satu keadaan, melainkan terus berpindah dari satu keadaan ke keadaan lain pada periode mendatang. Namun, perpindahan ini akan konstan dalam jangka panjang dan pada saat itulah proses mencapai keadaan tetap (Shukur, 2016).

Menurut Abdulrachman (1999), karena peluang dimulai tidak negatif dan proses harus melakukan transisi ke berbagai keadaan, maka:

$$
P_{i j} \geq 0 ; i, j \geq 0 ; \sum_{j=0}^{n} P_{i j}=1 ; i=0,1,2, \ldots, n
$$

Peluang transisi $P_{i j}$ dapat ditulis dalam matriks transisi P:

$$
P=\left[\begin{array}{cccc}
P_{00} & P_{01} & \ldots & P_{0 n} \\
P_{10} & P_{11} & \ldots & P_{1 n} \\
\vdots & \vdots & \ddots & \vdots \\
P_{n 0} & P_{n 1} & \ldots & P_{n n}
\end{array}\right]
$$

Karena unsur-unsur $\mathrm{P}$ adalah titik tidak negatif dan jumlah peluang semua unsur pada setiap baris adalah 1, maka setiap baris adalah vektor peluang dan $P$ adalah matriks stokastik. Matriks tersebut bersama dengan keadaan awal secara lengkap mendefinisikan suatu proses markov. Dengan kata lain, apabila informasi tersebut diketahui, kita dapat menentukan kejadian, misalnya pada step yang ke- $n$.

\section{Peluang Keadaan Tetap}

Menurut Mirah (2002), keadaan tetap adalah keadaan keseimbangan setelah proses berjalan selama beberapa periode. Peluang pada keadaan ini disebut peluang tetap yang nilainya tetap. Apabila keadaan tetap terjadi, maka peluang status periode $i$ akan sama dengan peluang pada status periode berikutnya $(i+1)$.

Peluang yang berakhir pada keadaan tertentu di masa mendatang tidak tergantung pada keadaan awal ini dikenal sebagai peluang keadaan tetap (steady state). Peluag keadaan tetap adalah peluang rata-rata bahwa suatu sistem akan berada dalam keadaan tertentu setelah sejumlah besar periode transisi. Hal ini tidak berarti bahwa sistem tersebut tetap dalam satu keadaan. Ia akan terus berpindah dari keadaan satu ke keadaan lain dalam periode mendatang. Namun, peluang rata-rata perpindahan dari satu keadaan ke keadaan lain untuk seluruh periode tetap konstan dalam jangka panjang. Dalam proses markov, setelah sejumlah periode berlalu, peluang akan mencapai keadaan tetap.

\section{Curah Hujan}

\section{Gambaran Umum Tentang Curah Hujan}

Cuaca adalah keadaan udara pada saat tertentu dan di wilayah tertentu yang relatif sempit dan pada jangka waktuyang singkat. Cuaca itu terbentuk dari gabungan unsur cuaca dan jangka waktu cuaca dalam waktu beberapa jam saja(Lakitan, 1997).

Iklim adalah keadaan cuaca rata-rata dalam waktu satu tahun yang penyelidikannya dilakukan dalam waktu yang lama ( \pm 30 tahun) dan meliputi wilayah yang luas (Lakitan, 1997). Klasifikasi Scmidt-Ferguson menggunakan nilai perbandingan (Q) antara rata-rata banykanya bulan kering (Md) dan rata-rata banyaknya bulan basah (Mf) dalam tahunan penelitian, adapun 
kategori untuk bulan kering (jika dalam satu bulan mempunyai jmlah curah hujan $<60 \mathrm{~mm}$ ), bulan lembab (jika dalam satu bulan mempunyai jumlah curah hujan 60 sampai $100 \mathrm{~mm}$ ), dan bulan basah (jika dalam satu bulan mempunyai jumlah curah hujan >100 mm) (Sasminto, 2014).

Curah hujan merupakan ketinggian air hujan yang terkumpul dalam tempat yang datar, tidak menguap, tidak meresap, dan tidak mengalir. Curah hujan 1 (satu) millimeter, artinya dalam luasan satu meter persegi pada tempat yang datar tertampung air setinggi satu millimeter atau tertampung air sebanyak satu liter. Curah hujan kumulatif $(\mathrm{mm})$ merupakan jumlah hujan yang terkumpul dalam rentang waktu kumulatif tersebut. Dalam periode musim, rentang waktunya adalah rata-rata panjang musim pada masing-masing Daerah Pakiraan Musim (DPM) (Mangostina, 2010).

Pada masa modern seperti sekarang ini pemanfaatan cuaca diperlukan pada bidang perhubungan darat, perhubungan laut, dan perhubungan udara. Pengamatan cuaca diperlukan sebagai upaya untuk mengurangi dampak bencana yang ditimbulkan oleh cuaca buruk yang biasanya akan mendatangkan bencana yang lebih besar (Asnida, 2015).

\section{Klasifikasi Curah Hujan}

Untuk kepentingan kajian atau praktis, hujan dibedakan menurut nilai intensitasnya dan kecepatan jatuhnya. Menurut BMKG (2006), klasifikasi hujan berdasarkan intensitas curah hujan, yakni:

- Hujan sangat lemah, apabila intensitas curah hujannya kurang dari $0,02 \mathrm{~mm} / \mathrm{min}$.

- Hujan lemah, apabila intensitas curah hujannya berkisar antara 0,002-0,05 $\mathrm{mm} / \mathrm{min}$.

- Hujan normal, apabila intensitas curah hujannya berkisar antara $0,05-0,25 \mathrm{~mm} / \mathrm{min}$.

- Hujan deras, apabila intensitas curah hujannya berkisar antara 0,25-1 $\mathrm{mm} / \mathrm{min}$.

- Hujan sangat deras, apabila intensitas curah hujannya lebih dari $1 \mathrm{~mm} / \mathrm{min}$.

Klasifikasi hujan dilihat dari kecepatan jatuhnya curah hujan terbagi atas:

- Hujan gerimis, apabila kecepatan jatuhnya berkisar $0,5 \mathrm{~m} / \mathrm{sec}$.

- Hujan halus, apabila kecepatan jatuhnya berkisar $2,1 \mathrm{~m} / \mathrm{sec}$.

- Hujan normal, apabila kecepatan jatuhnya berkisar 4-6,5 m/sec.

- Hujan sangat deras, apabila kecepatan jatuhnya berkisar $8,1 \mathrm{~m} / \mathrm{sec}$.

\section{Iklim Geografis di Kota Makassar}

Secara geografis kota Makassar terletak 119 24' 17" Bujur Timur (BT) dan 5 8' 6" Lintang Selatan (LS)

Batas-Batas wilayah:

Di sebelah Utara

: Kabupaten Maros

Di sebelah Selatan

: Kabupaten Gowa

Di sebelah Timur

: Kabupaten Maros

Di sebelah Barat

: Selat Makassar

Kota Makassar beriklim tropis dengan temperatur rata-rata berkisar antara $26,2^{\circ} \mathrm{C}-29,3^{\circ} \mathrm{C}$ dan kelembaban udara berkisar 77 persen dan rata-rata kecepatan angin 5,2 knot. Secara umum Kota Makassar mengalami musim hujan pada bulan November - April dan musim kemarau pada bulan Mei - Oktober. Curah hujan rata-rata tahunan sekitar $256.08 \mathrm{~mm} /$ bulan (Badan Pusat Statistika Kota Makassar, 2010).

\section{Pengukuran Curah Hujan}

Menurut Lakitan (1997),jumlah air hujan diukur menggunakan pengukur hujan atau ambrometer. Ia dinyatakan sebagai kedalaman air yang terkumpul pada permukaan datar, dan diukur kurang lebih $0.25 \mathrm{~mm}$. satuan curah hujan menurut SI adalah milimeter yang merupakan penyingkatan dari liter per meter persegi. Dengan segala kekurangan dan kelebihannya, alat 
pengukur hujan ada 2 macam yaitu alat pengukur curah hujan manual dan alat pengukur hujan otomatik.

\section{METODOLOGI PENELITIAN}

Penelitian ini merupakan penelitian terapan tentang model Rantai Markov dan data yang digunakan adalah data sekunder yaitu data curah hujan bulanan di tiga stasiun penakar curah hujan yaitu Panaikang, Biring Romang dan Paotere dari bulan Januari 1988 sampai dengan Desember 2016 yang diperoleh dari Balai Besar Meteorologi, Klimatologi, dan Geofisika (BMKG) Wilayah IV Makassar.

\section{HASIL DAN PEMBAHASAN}

\section{Menentukan State}

Kejadian adalah himpunan bagian dari ruang sampel yaitu suatu kejadian dengan kondisi tertentu. Ruang kejadian adalah kumpulan semua kejadian dari suatu percobaan statistik yang dinotasikan dengan $\mathrm{S}$.

$\mathrm{S}=\left\{X_{n}, n \geq 0\right\}$ dimana $X_{n}$ yaitu kondisi bulan (kering, lembab dan basah) dan dinyatakan dengan :

$$
X_{n}= \begin{cases}1 & \text { bulan kering (iika jumlah curah hujan kurang dari } 60 \mathrm{~mm} \text { ) } \\ 2 & \text { bulan lembab (iika iumlah curah huian } 60 \mathrm{~mm} \text { sampai } 100 \mathrm{~mm} \text { ) } \\ 3 & \text { bulan basah (iika jumlah curah huian lebih dari } 100 \mathrm{~mm} \text { ) }\end{cases}
$$

\section{Penentuan Orde Rantai Markov}

Pengujian ini bertujuan untuk menentukan orde yang digunakan dalam peramalan curah hujan pada periode berikutnya

\section{Uji antara orde 0 dan orde 1}

Hipotesis untuk pengujian orde 0 dan orde 1 sebagai berikut.

$$
\begin{array}{ll}
\mathrm{H}_{0}: p_{1 j}=p_{2 j}=p_{3 j}=p_{j} & j=1,2,3 \\
\mathrm{H}_{1}: \text { terdapat minimal satu } p_{i j} \neq p_{i} & i=1,2,3
\end{array}
$$

- Stasiun Panaikang

Frekuensi kondisi bulan pada saat $t-1$, dimana $t$ adalah Februari 1988 sampai Desember 2016 dapat dilihat pada Tabel 1.

TABEL 1. Frekuensi Kondisi Bulan Pada Saat $t-1$ Stasiun Panaikang

\begin{tabular}{cccc}
\hline Kering (1) & Lembab (2) & Basah (3) & Total \\
\hline 120 & 37 & 191 & 348
\end{tabular}

Untuk memperoleh nilai peluang transisi digunakan rumus peluang $P(A)=\frac{n(A)}{n(S)}$ sehingga diperoleh:

$$
p_{11}=\frac{n(1)}{n(S)}=\frac{120}{348}=0,34 p_{12}=\frac{n(2)}{n(S)}=\frac{37}{348}=0,11 \quad p_{13}=\frac{n(3)}{n(S)}=\frac{191}{348}=0,55
$$

Dengan demikian matriks peluang transisinya adalah :

$$
p_{i}=\left[\begin{array}{lll}
p_{11} & p_{12} & p_{13}
\end{array}\right]
$$




$$
p_{i}=\left[\begin{array}{lll}
0,34 & 0,11 & 0,55
\end{array}\right]
$$

Frekuensi transisi kondisi bulan dari $t-1$ ke $t$, dimana $t$ adalah Februari 1988 sampai Desember 2016 dapat dilihat pada Tabel 2.

TABEL 2. Frekuensi Transisi Kondisi Bulan dari $t-1$ ke- $t$ Stasiun Panaikang

\begin{tabular}{ccccc}
\hline Kondisi Bulan & Kering (1) & Lembab (2) & Basah (3) & Total \\
\hline Kering(1) & 78 & 20 & 22 & 120 \\
Lembab(2) & 13 & 5 & 19 & 37 \\
Basah(3) & 29 & 12 & 149 & 190 \\
\hline
\end{tabular}

Untuk memperoleh nilai peluang transisi digunakan rumus peluang $P(A)=\frac{n(A)}{n(S)}$ sehingga diperoleh:

$$
\begin{gathered}
p_{11}=\frac{n(1)}{n(S)}=\frac{78}{120}=0,65 p_{12}=\frac{n(2)}{n(S)}=\frac{20}{120}=0,17 \quad p_{13}=\frac{n(3)}{n(S)}=\frac{22}{120}=0,18 \\
p_{21}=\frac{n(1)}{n(S)}=\frac{13}{37}=0,35 p_{22}=\frac{n(2)}{n(S)}=\frac{5}{37} 0,14 p_{23}=\frac{n(3)}{n(S)}=\frac{19}{37}=0,51 \\
p_{31}=\frac{n(1)}{n(S)}=\frac{29}{190}=0,15 p_{32}=\frac{n(2)}{n(S)}=\frac{12}{190}=0,06 p_{33}=\frac{n(3)}{n(S)}=\frac{149}{190}=0,78
\end{gathered}
$$

Dengan demikian matriks peluang transisinya adalah :

$$
\begin{gathered}
p_{i j}=\left[\begin{array}{lll}
p_{11} & p_{12} & p_{13} \\
p_{21} & p_{22} & p_{23} \\
p_{31} & p_{32} & p_{33}
\end{array}\right] \\
p_{i j}=\left[\begin{array}{lll}
0,65 & 0,17 & 0,18 \\
0,35 & 0,14 & 0,51 \\
0,15 & 0,06 & 0,78
\end{array}\right]
\end{gathered}
$$

Untuk menguji hipotesis pada bagian (a) digunakan persamaan 2.5 uji statistik distribusi chi kuadrat dengan derajat kebebasan $s^{r-1}(s-1)^{2}$ dimana $H_{0}$ ditolak jika $X_{\text {hitung }}^{2}>X_{\text {tabel }}^{2}(\alpha)$.

$$
\begin{gathered}
x_{\text {hitung }}^{2}=2\left[\sum_{1}^{3} \sum_{1}^{3} n_{i j}\left(\ln p_{i j}-\ln p_{i}\right)\right] \\
x_{\text {hitung }}^{2}=2[78(\ln 0,65-\ln 0,34)+20(\ln 0,17-\ln 0,34)+22(\ln 0,18- \\
+\ln 0,34)+13(\ln 0,35-\ln 0,11)+5(\ln 0,14-\ln 0,11)+ \\
19(\ln 0,51-\ln 0,11)+29(\ln 0,15-\ln 0,55)+12(\ln 0,06- \\
+\ln 0,55)+149(\ln 0,78-\ln 0,55)] \\
x_{\text {hitung }}^{2}=115,55
\end{gathered}
$$

Dari tabel Chi Kuadrat dengan taraf signifikan $(\alpha)$ sebesar 0,05 dan derajat kebebasan sebesar 4 diperoleh $x_{\text {tabel }}^{2}=9,49$. Karena $x_{\text {hitung }}^{2}=115,55>X_{\text {tabel }}^{2}(\alpha)=9,49$ maka $H_{0}$ ditolak pada taraf signifikan $5 \%$. Hal ini berarti bahwa orde 0 dan orde 1 berbeda, maka akan dilanjutkan pengujian antara orde 1 dan orde 2. Begitupun pada stasiun Biring Romang dan Paotere diperoeh hasil yang sama yaitu $H_{0}$ ditolak pada taraf signifikan $5 \%$.

\section{Uji antara Orde 1 dan Orde 2}

Hipotesis untuk pengujian orde 1 dan orde 2 sebagai berikut.

$$
\begin{aligned}
\mathrm{H}_{0}: p_{1 j k}=p_{2 j k}=p_{3 j k}=p_{j k} \quad j & =1,2,3 \quad k=1,2,3 \\
\mathrm{H}_{1}: \text { terdapat minimal satu } p_{i j k} & \neq p_{j k} \quad i=1,2,3
\end{aligned}
$$


- Stasiun Panaikang

Frekuensi transisi kondisi bulan dari $t-1$ ke $t+1$, dimana $t$ adalah Februari 1988 sampai Desember 2016 dapat dilihat pada Tabel 3.

TABEL 3. Frekuensi Transisi Kondisi Bulan Dari $t-1 \mathrm{ke}-t+1$ Stasiun Panaikang

\begin{tabular}{|c|c|c|c|c|c|}
\hline \multicolumn{2}{|c|}{ Kondisi Bulan } & Kering (1) & Lembab (2) & Basah (3) & Total \\
\hline \multirow{3}{*}{ Kering (1) } & Kering (1) & 50 & 12 & 16 & 78 \\
\hline & Lembab (2) & 6 & 4 & 10 & 20 \\
\hline & Basah (3) & 3 & 0 & 19 & 22 \\
\hline \multirow{3}{*}{ Lembab (2) } & Kering (1) & 10 & 0 & 3 & 13 \\
\hline & Lembab (2) & 4 & 0 & 1 & 5 \\
\hline & Basah (3) & 5 & 1 & 13 & 19 \\
\hline \multirow{3}{*}{ Basah (3) } & Kering (1) & 18 & 8 & 3 & 29 \\
\hline & Lembab (2) & 3 & 1 & 8 & 12 \\
\hline & Basah (3) & 21 & 11 & 116 & 148 \\
\hline
\end{tabular}

Untuk memperoleh nilai peluang transisi digunakan rumus peluang $P(A)=\frac{n(A)}{n(S)}$ sehingga diperoleh:
$p_{111}=\frac{n(1)}{n(s)}=\frac{50}{78}=0,64$
$p_{112}=\frac{n(2)}{n(s)}=\frac{12}{78}=0,15$
$p_{113}=\frac{n(3)}{n(s)}=\frac{16}{78}=0,21$
$p_{121}=\frac{n(1)}{n(s)}=\frac{6}{20}=0,30$
$p_{122}=\frac{n(2)}{n(s)}=\frac{4}{20}=0,20$
$p_{123}=\frac{n(3)}{n(s)}=\frac{10}{20}=0,50$
$p_{131}=\frac{n(1)}{n(s)}=\frac{3}{22}=0,14$
$p_{132}=\frac{n(2)}{n(s)}=\frac{0}{22}=0,00$
$p_{133}=\frac{n(3)}{n(s)}=\frac{19}{22}=0,86$
$p_{211}=\frac{n(1)}{n(s)}=\frac{10}{13}=0,77$
$p_{212}=\frac{n(2)}{n(s)}=\frac{0}{13}=0,00$
$p_{213}=\frac{n(3)}{n(s)}=\frac{3}{13}=0,23$
$p_{221}=\frac{n(1)}{n(s)}=\frac{4}{5}=0,80$
$p_{222}=\frac{n(2)}{n(s)}=\frac{0}{5}=0,00$
$p_{223}=\frac{n(3)}{n(s)}=\frac{1}{5}=0,20$
$p_{231}=\frac{n(1)}{n(s)}=\frac{5}{19}=0,26$
$p_{232}=\frac{n(2)}{n(s)}=\frac{1}{19}=0,05$
$p_{233}=\frac{n(3)}{n(s)}=\frac{13}{19}=0,68$
$p_{311}=\frac{n(1)}{n(s)}=\frac{18}{29}=0,62$
$p_{312}=\frac{n(2)}{n(s)}=\frac{8}{29}=0,28$
$p_{313}=\frac{n(3)}{n(s)}=\frac{3}{29}=0,10$
$p_{321}=\frac{n(1)}{n(s)}=\frac{3}{12}=0,25$
$p_{322}=\frac{n(2)}{n(s)}=\frac{1}{12}=0,08$
$p_{323}=\frac{n(3)}{n(s)}=\frac{8}{12}=0,67$
$p_{331}=\frac{n(1)}{n(s)}=\frac{21}{148}=0,14$
$p_{332}=\frac{n(2)}{n(s)}=\frac{11}{148}=0,07$
$p_{333}=\frac{n(3)}{n(s)}=\frac{116}{148}=0,78$

Dengan demikian matriks peluang transisinya adalah:

$$
p_{i j k}=\left[\begin{array}{lll}
p_{111} & p_{112} & p_{113} \\
p_{121} & p_{122} & p_{123} \\
p_{131} & p_{132} & p_{133} \\
p_{211} & p_{212} & p_{213} \\
p_{221} & p_{222} & p_{223} \\
p_{231} & p_{232} & p_{233} \\
p_{311} & p_{312} & p_{313} \\
p_{321} & p_{322} & p_{323} \\
p_{311} & p_{332} & p_{333}
\end{array}\right]
$$




$$
p_{i j k}=\left[\begin{array}{ccc}
0,64 & 0,15 & 0,21 \\
0,30 & 0,20 & 0,50 \\
0,14 & 0,00 & 0,86 \\
0,77 & 0,00 & 0,23 \\
0,80 & 0,00 & 0,20 \\
0,26 & 0,05 & 0,68 \\
0,62 & 0,28 & 0,10 \\
0,25 & 0,08 & 0,67 \\
0,14 & 0,07 & 0,78
\end{array}\right]
$$

Untuk menguji hipotesis pada bagian (b) digunakan persamaan 2.5 uji statstik distribusi chi kuadrat dengan derajat kebebasan $s^{r-1}(s-1)^{2}$ dimana $H_{0}$ ditolak jika $x_{\text {hitung }}^{2}>x_{\text {tabel }}^{2}(\alpha)$.

$$
\begin{gathered}
x_{\text {hitung }}^{2}=2\left[\sum_{1}^{3} \sum_{1}^{3} \sum_{1}^{3} n_{i j k}\left(\ln p_{i j k}-\ln p_{i j}\right)\right] \\
x_{\text {hitung }}^{2}=2[50(\ln 0,64-\ln 0,65)+12(\ln 0,15-\ln 0,65)+16(\ln 0,21-\ln 0,65)+ \\
6(\ln 0,30-\ln 0,17)+4(\ln 0,20-\ln 0,17)+10(\ln 0,50-\ln 0,17)+ \\
3(\ln 0,14-\ln 0,18)+0(\ln 0-\ln 0,18)+19(\ln 0,86-\ln 0,18)+ \\
10(\ln 0,77-\ln 0,35)+0(\ln 0-\ln 0,35)+3(\ln 0,23-\ln 0,35)+ \\
4(\ln 0,80-\ln 0,14)+0(\ln 0-\ln 0,14)+1(\ln 0,20-\ln 0,14)+ \\
5(\ln 0,26-\ln 0,51)+1(\ln 0,05-\ln 0,51)+13(\ln 0,68-\ln 0,51)+ \\
18(\ln 0,62-\ln 0,15)+8(\ln 0,28-\ln 0,15)+3(\ln 0,10-\ln 0,15)+ \\
3(\ln 0,25-\ln 0,06)+1(\ln 0,08-\ln 0,06)+8(\ln 0,67-\ln 0,06)+ \\
21(\ln 0,14-\ln 0,78)+11(\ln 0,07-\ln 0,78)+116(\ln 0,78-\ln 0,78)] \\
\quad x_{\text {hitung }}^{2}=19,49
\end{gathered}
$$

Dari tabel Chi Kuadrat dengan taraf signifikan $(\alpha)$ sebesar 0,05 dan derajat kebebasan sebesar 12 diperoleh $x_{\text {tabel }}^{2}(\alpha)=21,03$. Karena $x_{\text {hitung }}^{2}=19,49<X_{\text {tabel }}^{2}(\alpha)=21,03$ maka $H_{0}$ diterima pada taraf signifikan $5 \%$. Hal ini berarti bahwa orde 1 dan orde 2 tidak berbeda. Begitupun pada stasiun Biring Romang dan Paotere diperoleh hasil yang sama yaitu $H_{0}$ diterima pada taraf signifikan $5 \%$.

Berdasarkan hasil yang diperoleh dari ketiga stasiun curah hujan yang digunakan pada penelitian ini menunjukkan bahwa antara orde 1 dan orde 2 tidak berbeda. Sehingga orde yang akan digunakan dalam peramalan curah hujan pada periode berikutnya adalah orde 1 .

Untuk memperoleh matriks transisi berikutnya pada masing-masing stasiun, maka:

- Stasiun Panaikang

- Stasiun Biirng Romang

$$
\begin{gathered}
P^{2}=\left[\begin{array}{lll}
0,65 & 0,17 & 0,18 \\
0,35 & 0,14 & 0,51 \\
0,15 & 0,06 & 0,78
\end{array}\right]\left[\begin{array}{lll}
0,65 & 0,17 & 0,18 \\
0,35 & 0,14 & 0,51 \\
0,15 & 0,06 & 0,78
\end{array}\right]=\left[\begin{array}{lll}
0,51 & 0,14 & 0,35 \\
0,35 & 0,11 & 0,54 \\
0,24 & 0,08 & 0,68
\end{array}\right] \\
P^{3}=\left[\begin{array}{lll}
0,43 & 0,13 & 0,44 \\
0,35 & 0,11 & 0,54 \\
0,29 & 0,09 & 0,62
\end{array}\right]
\end{gathered}
$$

$$
P^{2}=\left[\begin{array}{lll}
0,72 & 0,10 & 0,19 \\
0,32 & 0,14 & 0,54 \\
0,12 & 0,06 & 0,82
\end{array}\right]\left[\begin{array}{lll}
0,72 & 0,10 & 0,19 \\
0,32 & 0,14 & 0,54 \\
0,12 & 0,06 & 0,82
\end{array}\right]=\left[\begin{array}{lll}
0,57 & 0,10 & 0,33 \\
0,34 & 0,09 & 0,58 \\
0,20 & 0,07 & 0,73
\end{array}\right]
$$


- Stasiun Paotere

$$
P^{3}=\left[\begin{array}{lll}
0,48 & 0,09 & 0,43 \\
0,34 & 0,08 & 0,58 \\
0,25 & 0,07 & 0,67
\end{array}\right]
$$

$$
\begin{gathered}
P^{2}=\left[\begin{array}{lll}
0,71 & 0,10 & 0,19 \\
0,52 & 0,05 & 0,43 \\
0,15 & 0,04 & 0,82
\end{array}\right]\left[\begin{array}{lll}
0,71 & 0,10 & 0,19 \\
0,52 & 0,05 & 0,43 \\
0,15 & 0,04 & 0,82
\end{array}\right]=\left[\begin{array}{lll}
0,58 & 0,08 & 0,34 \\
0,46 & 0,07 & 0,47 \\
0,24 & 0,05 & 0,71
\end{array}\right] \\
P^{3}=\left[\begin{array}{lll}
0,50 & 0,07 & 0,42 \\
0,43 & 0,07 & 0,50 \\
0,30 & 0,05 & 0,65
\end{array}\right]
\end{gathered}
$$

Peluang peralihan pada keadaan seimbang merupakan peluang peralihan yang sudah mencapai kesemimbangan sehingga tidak akan berubah terhadap perubahan waktu yang terjadi.

\section{Stasiun Panaikang}

$$
P^{10}=\left[\begin{array}{lll}
0,35 & 0,11 & 0,55 \\
0,35 & 0,11 & 0,55 \\
0,35 & 0,11 & 0,55
\end{array}\right]
$$

- Peluang bulan mengalami kondisi kering pada pada ke-10 dalam keadaan seimbang tanpa memperhitungkan keadaan awal yaitu0,35.

- Peluang bulan mengalami kondisi lembab pada peroide ke-10 dalam keadaan seimbang tanpa memperhitungkan keadaan awal adalah 0,11 .

- Peluang bulan mengalami kondisi basah pada periode ke-10dalam keadaan seimbang tanpa memperhitungkan keadaan awal adalah 0,55.

Terlihat bahwa ketiga baris mempunyai elemen-elemen yang sama, jadi peluang transisi sudah berada dalam keadaan seimbang pada periode ke-10 dan untuk periode ke-11,12,13, dan seterusnya akan diperoleh matriks yang sama karena proses sudah mencapai keadaan tetap.

Stasiun Biring Romang

$$
P^{15}=\left[\begin{array}{lll}
0,33 & 0,08 & 0,59 \\
0,33 & 0,08 & 0,59 \\
0,33 & 0,08 & 0,59
\end{array}\right]
$$

- Peluang bulan mengalami kondsi kering pada periode ke-15dalam keadaan seimbang tanpa memperhitungkan keadaan awal yaitu0,33.

- Peluang bulan mengalami kondisi lembab pada peiode ke-15dalam keadaan seimbang tanpa memperhitungkan keadaan awal adalah 0,08.

- Peluang bulan mengalami kondisi basah pada peiode ke-15dalam keadaan seimbang tanpa memperhitungkan keadaan awal adalah 0,59.

Terlihat bahwa ketiga baris mempunyai elemen-elemen yang sama, jadi peluang transisi sudah berada dalam keadaan seimbang pada periode ke-15 dan untuk periode ke-16,17,18 dan seterusnya akan diperoleh matriks yang sama karena proses sudah mencapai keadaan steady state.

\section{Stasiun Paotere}

$$
P^{12}=\left[\begin{array}{lll}
0,39 & 0,06 & 0,55 \\
0,39 & 0,06 & 0,55 \\
0,39 & 0,06 & 0,55
\end{array}\right]
$$

- Peluang bulan mengalami kondisi kering pada periode ke-12dalam keadaan seimbang tanpa memperhitungkan keadaan awal yaitu0,39.

- Peluang bulan mengalami kondisi lembab pada peiode ke-12 dalam keadaan seimbang tanpa memperhitungkan keadaan awal adalah 0,06. 
- Peluang bulan mengalami kondisi basah pada periode ke-12dalam keadaan seimbang tanpa memperhitungkan keadaan awal adalah 0,55.

Terlihat bahwa ketiga baris mempunyai elemen-elemen yang sama, jadi peluang transisi sudah berada dalam keadaan seimbang pada periode ke-12 dan untuk periode ke-13,14,15 dan seterusnya akan diperoleh matriks yang sama karena proses sudah mencapai keadaan steady state.

\section{KESIMPULAN}

Kesimpulan yang diperolehdari penelitian ini adalah sebagai berikut.

1. Peluang transisi Stasiun Panaikang pada periode ke-10 sudah mencapai keadaa steady state yaitu 0,35 bulan mengalami kondisi kering, 0,11 bulan mengalami kondisi lembab dan 0,55 bulan mengalami kondisi basah.

2. Peluang transisi Stasiun Biring Romang pada peride ke-15 sudah mencapai keadaan steady state yaitu 0,33 bulan mengalami kondisi kering, 0,08 bulan mengalami kondisi lembab dan 0,59 bulan mengalami kondisi basah.

3. Peluang transisi Stasiun Paotere pada periode ke-12 sudah mencapai keadaa steady state yaitu 0,39 bulan mengalami kondisi kering, 0,06 bulan mengalami kondisi lembab dan 0,55 bulan mengalami kondisi basah.

Pada peneliti berikutnya diharapkan menggunakan keadaan yang lain untuk diprediksi atau menggunakan metode lain untuk melakukan perbandingan dengan rantai markov serta menggunakan matriks yang berordo lebih tinggi.

\section{DAFTAR PUSTAKA}

Abdulrachman, E. (1999). Konsep Dasar Markov Chain serta Kemungkinan Penerapannya di BidangPertanian. JurnalInformatikaPertanian Vol (8).Hal 499-504.

Anderson, T.W. \& Goodman, L.A. (2014). Statistical Inference about Markov Chains. Journal The Annals of Mathematical Statistics, halaman 100. Columbia University and University of Chicago.

Asnida, B. (2015). Model Vektor Autoregressive untuk Peramalan Curah Hujan di Kota Makassar. (Skripsi, tidakdipublikasikan). Universitas Negeri Makassar.

Badan Pusat Statistika Kota Makassar.(2010). Makassar dalam Angka 2010 (Makassar in Figure 2010). UD Areso. Makassar.

BMKG. (2006). Prakiraan Musim kemarau tahun 2006 di Indonesia. Makassar. Badan Meteorologi dan Geofisika.

Dwijanto. (2012).http://masdwijanto.files.wordpress.com.bab-7.pdf.diakses pada tanggal 20 November 2017.

Lakitan, B. (1997). Dasar-Dasar Klimatologi. Jakarta. Raja Grafindo Persada.

Luk. (2001). Penerapan Metode Exponensial Smoothing Holt-Winter dalam Sistem Peramalan Curah Hujan.(Skripsi,tidak dipublikasikan). Universitas Pendidikan Indonesia.

Mangostina, C. (2010). Curah Hujan. http://bidinagtuns.blogspot.com/2010/11/curah-hujan. diakses pada tanggal 15 November 2017.

Mirah. (2002). Analisis Markov. http://gustimirah.blogspot.com/2009/12/analisis-markov.html diakses pada tanggal 15 November 2017. 
Nawangsari, S., Iklima, F.M.,\&Wibowo, E.P. (2008). Konsep Markov Chain Untuk Menyelesaikan Prediksi Bencana Alam Di Wilayah Indonesia Dengan Studi Kasus Kotamadya Jakarta Utara. Jurnal: Universitas Gunadarma.

Paida. (2011). Deteksi Perubahan Pola Curah Hujan Kota Makassar. (Skripsi, tidak dipublikasikan). Universitas Hasanuddin Makassar.

Reza, M. (2007). Penentuan Peluang Transisi t langkah dan Uji Orde dari Suatu Rantai Markov (Studi kasus: Barisan basa nukleotisida Homo Sapiens).(Skripsi, tidak dipublikasikan). Institut Tegnologi Bandung.

Sasminto, R.A., Tunggul, A.,\&Rahadi B.J. (2014). Analisis Spasial Penentuan Iklim Menurut Klasifikasi Schmidt-Furgeson dan Oldeman di Kabupaten Ponorogo. Jurnal Sumber Daya Alam \& Lingkunagn. Vol (1).Hal 51.

Shukur, M. 2016. Penerapan Analisis Markov Pada Kasus Angsuran Kartu Halo di PT. Infomedia Solusi Humanika Makassar. (Skripsi, tidak dipublikasikan). Universitas Negeri Makassar. 